\title{
Pradhan Mantari Jan Aushadi Kendra - Demonetarization of Medicine Prices in India
}

Vinuth Chikkamath and Anantha Naik Nagappa*

SCS College of Pharmacy, Harapanahalli, Karnataka, India

*Corresponding author: Anantha Naik Nagappa, SCS College of Pharmacy, Harapanahalli, Karnataka, India, Tel: +919900407416; Email:anantha1232000@gmail.com

Received date: November 23, 2016; Accepted date: December 29, 2016; Published date: December 30, 2016

Copyright: (c) 2016 Chikkamath V, et al., This is an open-access article distributed under the terms of the Creative Commons Attribution License, which permits unrestricted use, distribution, and reproduction in any medium, provided the original author and source are credited.

\begin{abstract}
Demonetarization of currency notes of five hundred rupees and thousand rupees denominations is hailed because of surgical strike against black money, terrorist funding and also corruption. On the comparative lines the Government of India has introduced Jan Aushadhi scheme to give jolt to the uncontrolled medicine prices across all therapeutic category of medicines in India. Although brand medicines in India appear cheap when compared with international prices, however the brand medicines in India are expensive in comparison with generic medicines. The brand medicines despite being expensive are preferred over generic medicines by the prescribers due to exhaustive marketing practices by the manufactures. Although generic medicines are available at affordable prices they are not preferred over brand medicines. The price sensitivity for medicine appears to be very low. Generic medicines are less popular for various reasons, primarily due to marketing techniques of luring the prescribers brand medicines. The medicine prices are bound to get down to the ground levels when enactment of Jan Aushadhi Act is implemented in true spirit with a strong political will.
\end{abstract}

Keywords: Jan Aushadhi Act; Generic medicines; Brand medicines

\section{Introduction}

Medicines are the vital components of therapeutics which are manufactured, distributed and sold to the patients under various regulations like Drugs and Cosmetics Act and Drug Price Control. The handlings of drugs at various stages are carried out by a team of healthcare provider's viz., Doctors, Pharmacist and Nurses. Healthcare professionals are registered and regulated by respective statutory bodies. The PCI is supposed to monitor, nurture and maintain standards of Pharmacy profession in India. Similarly Medical council of India and Nursing council of India are responsible for establishment and maintaining of respective professional practices. The objective of the council is to establish professional standards. All the councils have failed to maintain the professional standards in the country [1]. Collaborative healthcare in which the contributions of Doctor, Pharmacist and Nurses in team work to ensure patient safety and optimize acceptable outcomes is a mirage in healthcare delivery. In India healthcare practice is greatly influenced by the lobby of Pharmaceutical industry and organizations of Doctors and Pharmacist. These organizations are meant to protect interest of their members of pharmaceutical industry and organization has not shown interest in public healthcare issues like affordability and medicine prices. The Pharmaceutical industries are governed by Drugs and Cosmetics Act, Drugs and Magic remedies Act, Narcotic drugs and poisons Act and Drug price control order, they are supposed to protect the patients and health consumers from the danger and damages caused by irrational prescription medicines. Drug safety is a major issue of healthcare provision, which is masked by the corrupt practice of the healthcare providers. Distribution and sale of medicines are governed by Drugs \&Cosmetics Act (Schedule N) and Pharmacy Act. The pharmacists are licensed to establish whole sale outlet and retail outlets as per the provisions of the Drugs and Cosmetics Act. The Pharmacist is a custodian for all prescription medicines and I supposed to dispense the medicines against prescription by a registered medical practitioner. It is an offence to sell prescription medicines without prescription to patients and health consumers. The pharmacists also establish the organization and offices across the countries that are involving in protecting the interest of their own members rather than public health [2].

All therapeutic medicines carry a risk on health. Hence they are capable of inflicting serious injury and damage if they are used indiscriminately. Every medicine has dose response relationship. The response of the drug is usually determined by the concentration of drug in the blood. There are two critical concentrations which determine the response of the drug on the human body, the minimum critical concentration and minimum toxic concentration. The gradient between minimum toxic concentration and minimum effective concentration is known as the therapeutic window. It is desirable that the drug concentration should remain below the minimal toxic concentration, if the concentration exceeds minimum toxic concentration the drug is likely to act like poison leading to various adverse drug reactions and organ damage. For example the drugs like gentamycin which is known to cause damage to kidney and the blood levels, should be monitored while using and never be allowed to exceed the minimum toxic concentration. Some important drug related various vital organs toxicity is listed in (Table 1). The potential risk of health in therapeutics need to be documented and revived by continuous surveillance of effect of drugs on human health. The Pharmacovigilance which was not carried out in earlier times has gained much importance in recent times. The patient safety has become more important than therapeutic efficacy as the medicines are causing much harm than being useful. Indiscriminate use of medicines is bound to cause severe ill effects on human health. Hence the government of India has made it mandatory for all the Pharma industries to establish the Pharmacovigilance program for its own 
products and submit data for continuing the licenses for marketing the product.

\begin{tabular}{|c|c|c|c|}
\hline Name of the drug & Category & Therapeutic Applications & Concentration related Toxicity \\
\hline Aceclofenac & Non-steroidal Anti-inflammatory(NSAID) & Analgesic and Anti-inflammatory & Hepatotoxicity \\
\hline Cefixime & Cephalosporin antibiotic & To treat bacterial infection & Hepatotoxicity \\
\hline Cyclosporine & Immunosuppressant's & To prevent organ rejection in organ transplant & Nephrotoxicity \\
\hline Gentamicin & Amino glycoside antibiotic & To treat bacterial infection & Ototoxicity \\
\hline Nimesulide & COX-2, NSAID & Analgesic and Antipyretic & Hepatitis and acute liver failure \\
\hline Paracetamol & NSAID & Analgesic and Antipyretic & Hepatotoxicity \\
\hline Ranitidine & Histamine-2 blockers & To treat peptic ulcer & Nephrotoxicity \\
\hline Vancomycin & Glycopeptide antibiotics & To treat serious bacterial infection & Nephrotoxicity \\
\hline
\end{tabular}

Table 1: Drugs induced Concentration related Organ toxicity.

The collected data from various companies are analyzed by the Central Drugs Standard Control Organization (CDSCO). After reviewing the data the risk of the medicine over the benefits is analyzed by CDSCO and has been empowered to recommend banning of the unsafe medicines. This data is shared with world Pharmacovigilance center in Uppsala, Sweden for further scrutiny of Global policy recommendations.

The International Pharmacovigilance program is promoted by World health Organization located in Uppsala, Sweden. The aim of Pharmacovigilance is to collect various adverse drug reactions caused by medicines and view the collected signals across the world to identify the cause and magnitude of adverse drug reaction (ADR). If the risks involved are serious then they further alert the various governments to ban unsafe drugs by respective governments [3]. India is described as den of poor man medicines. Indian pharmaceutical sector produces quality branded and generic medicines in most of therapeutic categories. In 2012, industry had a business of one lakh ninety thousand crores Indian Rupee rates, even though the medicines are priced reasonably cheaper in comparison to global prices. Despite of the availability of cheap medicines majority of Indians afford the branded medicine. The brand medicines in India are registered just by name, packaging and other external features rather than the quality and intellectual property. Hence a brand in India is not having any advantage to patient and consumers in terms of safety and efficacy. The patients are made to buy expensive brand, which looks attractive in terms of presentation and does not offer any benefit as medicine. In India there are one lakh brand medicines which are registered, and are made by one thousand Active Pharmaceutical Ingredient.

There are many "Me Too" formulations marketed in the country. Most of these brands pose a burden to various stake holders. Doctors are unable to remember the medicines by active pharmaceutical ingredients and are prescribing the brand with lot of hesitations. Similarly the pharmacists are also facing the problem due to short lived market of brands. It is causing the waste of investment on inventory and confusing the health care providers. The other issues like management of drug stores becoming the difficult due look like and sound like names of the brands. To resolve this issue, the government of India enacted Jan Aushadhi Act 2008. The Price control of prescription medicines is the one of the major objective of Jan Aushadhi Act Kendra has to sell generic medicines. The National pricing control of prescription drugs has begun through the National drug pricing authority under the drug price control order in 1995.

The Drug price control Act 1995 has given the guidelines for fixing the maximum retail price of brand medicines, bulk drugs and their formulations. Further government of India has established National pricing authority in order to deliver the objective of Drug Price Control Act 1995 and National Pharmaceutical Pricing Authority (NPPA) is to establish Bureau of Pharma PSUs of India (BPPI) has given call for opening of medical shops called Jan Aushadhi Kendra [4]. The Government of India backward integration is updating by reviewing public sectors Hindustan antibiotics in Pune, Karnataka Antibiotics \& Pharmaceuticals Limited Bengaluru. The medicines manufactured in this public sector are likely to reach for sales in Jan Aushadhi Kendra's. The government of India has also instructed doctors working in government hospitals to prescribe the generic medicines instead of brand medicines. By doing so government wants to challenge the dominance brand medicines in private structure by the launch of Jan Aushadhi scheme in 2008 and encouraging the establishment of exclusive generic drug stores. Government of India wants to play a key role. The Government of India by utilizing the local resources for manufacture, distribution and sale of prescription medicines has established study supply. (Table 2) Here is list of the generic drugs that are sold at predetermined affordable price to the public [5]. At present 651 formulations of generic medicines are sold through exclusive Jan Aushadhi Kendra's.

The Jan Aushadhi Kendra's are franchises of BPPI. The generic medicines are likely to dislodge the demand for expensive branded medicines which are sold in the market by adopting unethical marketing practice by the private pharmaceutical industries [7].

The brand medicines in India are marketed by prescription of a medical practitioner and hence the doctors are pampered by the Pharma industries to sell the branded medicines despite of being expensive. 
Citation: Chikkamath V, Nagappa AN (2016) Pradhan Mantari Jan Aushadi Kendra - Demonetarization of Medicine Prices in India. J Gen Pract

Page 3 of 5

\begin{tabular}{|c|c|c|c|c|c|c|c|}
\hline S.no & Name of medicine & Therapeutic class & Unit & $\begin{array}{l}\text { Jan aushadhi } \\
\text { price } \\
\text { (including all } \\
\text { taxes) }\end{array}$ & Brand & $\begin{array}{l}\text { Brand price } \\
\text { (including all } \\
\text { taxes) }\end{array}$ & $\begin{array}{l}\text { Differnce in } \\
\text { price }\end{array}$ \\
\hline 1 & $\begin{array}{l}\text { Aceclofenac+Paracetamol } \\
(100 \mathrm{mg}+500 \mathrm{mg}) \text { Tablet }\end{array}$ & Analgesic & 10 's & 14.49 & Zerodol-P (Ipca) & 38.5 & 24.01 \\
\hline 2 & $\begin{array}{l}\text { Acetaminophen+Tramadol } \\
\text { Hydrochloride }(325 \mathrm{mg}+375 \mathrm{mg}) \\
\text { film coated tablet }\end{array}$ & $\begin{array}{l}\text { Analgesic/Anti } \\
\text { inflammatory }\end{array}$ & 10 's & 8.16 & $\begin{array}{l}\text { Ultacet } \\
\text { (Johnson\& } \\
\text { Johnson) }\end{array}$ & 142 & 133.8 \\
\hline 3 & Amikacin 100 mg inj & $\begin{array}{l}\text { Antibacterial } \\
\text { (Antibiotic) }\end{array}$ & Vial & 15.04 & $\begin{array}{l}\text { Amiject } \\
\text { (Alkem) }\end{array}$ & 27 & 11.96 \\
\hline 4 & Cefixime (50 mg/5 ml) Dry syrup & $\begin{array}{l}\text { Antibacterial } \\
\text { (Antibiotic) }\end{array}$ & $30 \mathrm{ml}$ & 25.93 & $\begin{array}{l}\text { Taxim-O } \\
\text { (Alkem) }\end{array}$ & 42.21 & 16.28 \\
\hline 5 & Glimepiride 1 mg Tab & Anti-diabetic & 10 's & 3.48 & Glimestar-1 (Mankind) & 22 & 18.52 \\
\hline 6 & $\begin{array}{l}\text { Insulin Injection IP } 40 \quad \mathrm{IU} / \mathrm{ml} \\
\text { (Insulin Human Recombinant) }\end{array}$ & Anti-diabetic & $10 \mathrm{ml}$ & 118.61 & $\begin{array}{l}\text { Huminsulin } \\
\text { (Eli Lilly \& Company) }\end{array}$ & 141.24 & 22.63 \\
\hline 7 & Albendazole $(200 \mathrm{mg} / 5 \mathrm{ml})$ syrup & Anthelmintic & $\begin{array}{l}10 \mathrm{ml} \\
\text { bottle }\end{array}$ & 14.3 & $\begin{array}{l}\text { Band } \\
\text { (Mankind) }\end{array}$ & 17.1 & 2.8 \\
\hline 8 & $\begin{array}{l}\text { Omeprazole } 20 \mathrm{mg} \text { film coated } \\
\text { Tablets }\end{array}$ & GERD & 10 's & 10.03 & Omez (Dr. Reddys) & 36.36 & 26.33 \\
\hline 9 & $\begin{array}{l}\text { Pantaprazole } 40 \mathrm{mg} \text { film coated } \\
\text { Tablets }\end{array}$ & GERD & 10's & 9.97 & $\begin{array}{l}\text { Pan-40 } \\
\text { (Alkem) }\end{array}$ & 120 & 110 \\
\hline 10 & Atenolol $50 \mathrm{mg}$ Tablet & $\begin{array}{l}\text { Anti } \\
\text { hypertensive }\end{array}$ & $14 \times 10$ & 55.57 & $\begin{array}{l}\text { Aten50 } \\
\text { (ZydusCadila) }\end{array}$ & 24.4 & 31.17 \\
\hline 11 & $\begin{array}{l}\text { Alprazolam } 0.5 \mathrm{mg} \text { film coated } \\
\text { Tab }\end{array}$ & Anti-anxiety & 10 's & 3.97 & Anxit (Micro Labs) $1 \times 15$ & 34.96 & 30.99 \\
\hline 12 & $\begin{array}{lll}\text { Dexamethasone } & \text { Tablet } & \text { I.P. } \\
\text { Strength } 0.5 \mathrm{mg} & & \end{array}$ & $\begin{array}{l}\text { Anti } \\
\text { Inflammatory/ } \\
\text { Anti-allergic }\end{array}$ & 10 's & 3.69 & $\begin{array}{l}\text { Dexona } \\
\text { (ZydusAlidac) } 1 \times 20\end{array}$ & 3.78 & 0.09 \\
\hline 13 & Betamethasone Tablet IP $0.5 \mathrm{mg}$ & Anti-fungal & 20 's & 6.74 & $\begin{array}{l}\text { Betnesol } \\
\text { (gsk) }\end{array}$ & 8.1 & 1.36 \\
\hline 14 & Clotrimazole $100 \mathrm{mg}$ vaginal Tab & Fungicide & 10 's & 11.93 & $\begin{array}{l}\text { Candid-V6 } \\
\text { (Glen mark) }\end{array}$ & 60.32 & 48.39 \\
\hline 15 & Dusting Powder (Povidone 5\%) & Antiseptics & $10 \mathrm{gm}$ & 28.62 & $\begin{array}{l}\text { Intadine } \\
\text { Intas } \\
\text { Pharmaceuticals }\end{array}$ & 29.7 & 1.08 \\
\hline
\end{tabular}

Table 2: Comparison of prices of brand and Generic medicine [6].

Doctors are provided with expensive gifts and incentives and sometimes even cash to prescribe the specific brands. This has caused great damage to the professional practice of healthcare. It is observed that the doctors themselves are indulged in the sale of medicines to the patients directly in the hospital premises. The patients who have trust on the doctors are getting duped by the doctors who have become extremely greedy. This is also linked to the high cost of medical education. On the other hand the chemist and druggist are also responsible for sale of prescription medicines without prescription. They are selling prescription medicines to the public as the income of Pharmacy is mainly determined by the volume of sale of medicines. Recently they are given a call for an all India protest demanding favoring the business opportunities. The pharmacists have forgotten their role and responsibility of protecting public health of patients and 
customers. If the good quality of medicines are made available at an affordable price by the Government then public acceptance is possible. In order to achieve this objective the government itself has initiated the Jan Aushadhi Yojana in which generic medicines are sold. The Prime Minister of India realizing the socio-economic value of the project adopted the generic aushadhi Kendra's which is known as Prime minister Jan aushadhi Kendra. In this scheme an individual pharmacist, a NGO and the government agencies are invited to open a PMJAK. PMJAK should also apply for a license which is needed from the state drugs control department of respective state [8].

PMJAK license holder who is a registered pharmacist earns a $20 \%$ commission on sales and is also encouraged with one time subsidy of 2.5 lakh Indian Rupees Rate. The PMJAK are not allowed to sell the branded prescription medicine. However they are allowed to sell other products like cosmetic and general items.

The branded medicines are expensive because the pharmaceutical industry invests lavishly in building a brand image for the product. For example Hematinic liquid orals are presented in an attractive bottle with an eye catching label packed in an expensive cartoon. The Hematinic brand image is built by giving advertisement in various medical journals and mass media. Further they are engrossed by the celebrities who pay huge money. For marketing Hematinic brand products the company provides free samples for prescribes. They also give attractive schemes for drug stores, for example buy 10 bottles-get 10 bottles free. The medical shops also behave like trade unions, putting the conditions for marketing the product in their territory. They also demand trade bonus in the form of gifts and compliments. The Pharma Company has to spend money to push the products all along the product supply chain. Above all this, the company has to make the substantial profits which add on the price of brand medicine [9].

The definition of Generic medicines is different in India to the definition of generic medicines in the regulated markets like North America and Europe. As per the international norms the generic medicine is the one, which is licensed to sell by the drug name instead of brand name after the expiry of the patent period. The market exclusivity of innovator brand ceases to be null and void of the expiry of the patent period. The competitors of the innovator company develop the generic version by formulating the medicine which is exactly similar in terms of bioavailability and bioequivalence. The development of generic medicine involves establishing the formulation which is identical to Bioavailability and Bioequivalence generally in terms of pharmacokinetic and Pharmacodynamics parameters these formulations.

The Clinical data should be submitted to the regulators like US Food and Drug Administration (USFDA) for getting approval to sell in the US/Europe. After verifying the data for its correctness, USFDA gives license to sell the generics. Generics are comparatively cheaper than innovator brand. There will be no difference as per the therapeutic outcome is concerned. The generic medicines are advocated by insurance companies to save the money on prescription medicines (Figure 1) [10].

However the generic medicines in India mean an alternative similar formulation which is labeled by the generic name without any brand name. The formulations are packed with necessary requirements and costs on attractive packaging marketing expenses are cut. It may not be similar in terms of Pharmacokinetic/Pharmacodynamics requirements Bioavailability and Bioequivalence.

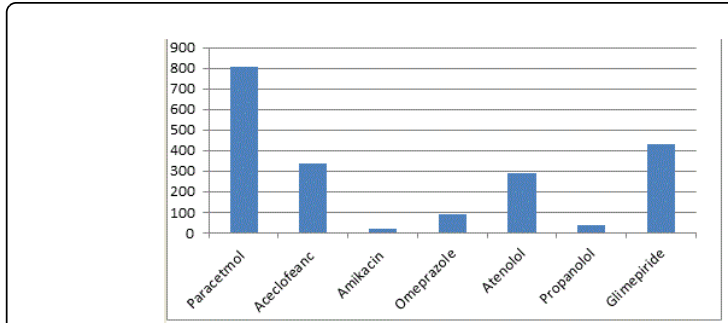

Figure 1: Brand medicines available in the Indian market [11].

The generic medicines in India means a plane formulation which is not promoted vigorously like brand medicine and are sold at a cheap price. It is now clear that the marketing of generic medicines is disturbing brand medicine market which would bring the expenditure of medicines for Government and Public. In India expenditure of medicines are paid by out of pocket model. There are issues and bottles necks for the coverage of patient's medicine expenses by health insurance schemes [12].

It is logical for the government to make an alternative arrangement for distribution of good quality medicines at an affordable price. Hence in 2008 the Jan Aushadhi scheme was launched which lead to the launch of new scheme called Pradhan Mantri Jan Aushadhi Kendra (PMJAK). Currently the Bureau of Pharma public sector units of India (BPPI) centralizes the manufacture, distribution of generic medicines to PMJAK. In order to encourage the entrepreneur, the government of India shall be paying 2.5 lakh INR as incentives for PMJAK in a phased manner. The PMJAK should sell only generic medicines listed in Jan Aushadhi price list. They are supposed to use the software given by BPPI. Every medicine sold to patient is sent online automatically [13].

\section{Conclusion}

Indian pharmaceutical market is flooded with brand formulations exceeding more than one lakh. This scenario has created serious issues in implementing drug regulations, evaluation of the quality of the products and management of inventory in retail drug stores confusing the prescribes and Pharmacists etc. In India the product registration and approval of brand name is done by Drug Control Department individual states. However the product gets licenses all across the country. As a result of this the local manufactures by registering the products in one state are marketing all across the country.

There are nearly thousand number of Pharma industry, involved in manufacture and sales of brand medicines. The brand medicines Quality control and Quality assurance of the products available in the market cannot be effectively done, as it requires huge infrastructure and drug analysis. Hence Quality assurance and Quality control are the in house responsibility of the industrialist. However they are also cross checked by the Drug control department in between. Hence the qualities of medicines are certified by the analyst appointed by the company.

The government of India has carried out nationwide survey by collecting samples of brand medicines from the open market and subjecting it to analysis for content and quality of the medicine. The preliminary report indicates a huge cap in a label claim in content in brand formulation. 
The large number of brand formulations in the market poses a challenge the prescriber and the retail Pharmacists. The look alike and the sound alike (LASA) is one of the causes of medication error and patient safety. The retail pharmacist has to maintain a huge inventory as market is flooded with "Me-To" brand medicine see (Table 3).

\begin{tabular}{|l|l|l|}
\hline S.no & Classification of drugs & Examples \\
\hline 1 & Non-Steroidal Anti-inflammatory drugs & Aceclofenac, Paracetamol, Tramadolol, Nimesulide etc. \\
\hline 2 & Antibiotics & Amikacin, Cefixime, \\
\cline { 2 - 3 } & & Tetracycline, Penicillin etc \\
\hline 3 & Beta-Blockers & Atenolol, Propanolol, Timolol, Sotalol, Pindalol etc \\
\hline 4 & Proton Pump inhibitors & Pantaprazole, Omeprazole \\
\hline 5 & Sulfonylurea antidiabetic drug & Glimepiride, Glipizide,Tolbutamide \\
\hline 6 & Anxiolytic of the Benzodiazepine class & Alprazolam, Clonazepam, Lorazepam etc. \\
\hline 9 & Anthelmintic of the Benzimidazole & Albendazole, Mebendazole, triclabedazole etc. \\
\hline 10 & Antifungal of the Azole derivatives & Clotrimazole, Econazole \\
\hline 11 & Steroidal class of corticosteroid & Betamethasone, Dexamethasone etc \\
\hline
\end{tabular}

Table 3: "Me-Too" brands in the Indian market [14].

The price of the brand medicines are very high and insisted by the doctors to use costly medicines. Despite of being highly priced the branded medicines are able to sell in the market by advertising, endorsing the doctors for the kick back by the manufactures. The government of India has a promise to full fill to the patients to provide quality medicines at an affordable price and they also wanted to have direct control over the pricing of medicine in the open market to achieve its objective the Government of India revitalized Jan Aushadhi outlets with an intent to outreach generic medicine to the patients. Big opposition has come from Doctors and Pharmacists side as they are thinking negatively regarding the generic medicines and are deliberately not promoting the generic medicines. The medical council of India in its recent circular has compelled all the Doctors in government hospital and public hospitals to write the prescriptions in generic name instead of brand name.

One special advantage of writing the generic name is that it helps the pharmacist to select other brand names which are suitable for patient's pocket. Here the pharmacist can open a dialogue with patients regarding the advantages of generic medicines.

The Pharmacist who understands the drug in manner (Medicinal chemistry, mechanism of action, therapeutic action and adverse drug reaction) can work on prescription identifying the drug related problems. He can share the inform with doctors and nurses thus helping to achieving the patient safety. Pharmacist can also suggest cheap and quality medicines and sensitize them about high cost of brand medicine. This could bring down the prices of brand medicines due to price competitions.

\section{References}

1. Rohit SR, Nilesh LB, Ravikiran KB, Pallavi CM, Pramod K. (2012) The Indian Pharmaceutical Industry Evolution of Regulation System and Present Scenario. IRJP 3: 49-55.

2. Priyanka PV (2015) Drug Regulation in India swot Analysis. IJDRA 3: 21-27.

3. Darekar A, Patel I, Clemons M, Xi Tan, Rana R, Bhatia D, Chang J (2016) Dispensing Practices in India and United States. J.pharm.pract.Community med 2: 60-64.

4. Singh B, Nanda A, Budhwar V (2015) An Update on Initiatives Taken By Indian Government to Promote Generic Medicines. IJPRBS 4: 26-38.

5. Singhal GL, Anita K, Arun N (2011) Jan Aushadhi Stores In India and Quality of Medicines Therein. Int J Pharm Pharm Sci. 1: 204-207.

6. (2015) Jan aushadhi - price list w.e.f.

7. (2016) Guidelines to be followed for submission/processing of applications for opening of Jan Aushadhi Generic Drug Stores.

8. (2016) Executive Summary.

9. Khan AN, Khar R K (2015) Current Scenario of Spurious and Substandard Medicinesin India A Systematic Review. Indian J. Pharm. Sci 77: 2-7.

10. Gupta SA, Nayak RP, Vidyarthi SK (2015) A Study on the Knowledge Attitude and Practice of Generic Medicines among the Doctors in a Tertiary Care Teaching Hospital in South India. Natl J Physiol Pharm Pharmacol 1: 39-44.

11. https://docs.google.com/file/d/0BxvjJ4mG_bfYdlExTnZYVVF0MVU/

12. http://www.medindia.net/drug-price/htm

13. http://janaushadhi.gov.in/

14. Tripathi KD (2016) Essentials of Medical Pharmacology. 7th Edition. Jaypee Brothers Medical Puiblishers Pvt Ltd, India. 